\title{
Three Awards and One Grant of the Li Fang-Kuei Society for Chinese Linguistics \\ 李方桂學會三種獎項及一種補助
}

Three Awards and One Grant are set up in memory of the contribution to Chinese Linguistics by the Master Linguist, the late Professor Li Fang-Kuei:

紀念李方桂先生中國語言學研究學會（以下簡稱「本會」）為紀念語言學大師李方桂先生對中國 語言學的貢獻, 特設立以下三種獎項及一種補助：

1. LFKS Book Award 李方桂學會語言學論著獎

2. LFKS Dissertation Award

李方桂學會博士論文獎

3. LFKS Field Work Award

李方桂學會田野調查獎

4. $\quad$ LF KS Graduate Student Conference Travel Grant

李方桂學會研究生學術會議旅費補助

For details of these awards and grant and their application procedures, please see our web site www .lfksociety.org.

獎項及旅費補助的內容及其申請辦法，詳見本學會網站 www.lfksociety.org。

According to Internal Revenue Service regulations, applicants for these awards and the grant cannot serve on the Board of Directors or be Officers of, or major donors to, the Li Fang-Kuei Society of Chinese Linguistics, nor can the applicants be closely related to them. ${ }^{1}$

按美國聯邦稅務局條例, 申請人不得為本會執行委員、董事、主要捐款者, 或與之有密切關係 者。2

1 "Major donors" refers to donors of over US\$5, ooo or of an accumulated amount over $2 \%$ of the endowment of the Li FangKuei Society.

2 “主要捐款者”指捐款總額超過 5,000 美元或者迄今捐款超過本會基金總數百分之二的人。 